\title{
Electricity Generation from Cow Dung Biogas
}

\author{
${ }^{1 *}$ AKPOJARO, J; ${ }^{2}$ OFUALAGBA, G; ${ }^{2}$ AKPOJARO, MA

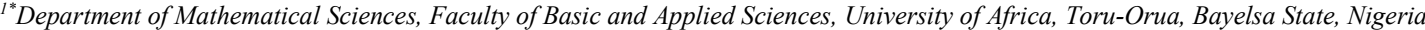 \\ ${ }^{2}$ Department of Electrical and Electronics Engineering, Faculty of Engineering, Federal University of Petroleum Resources, Effurun, \\ Nigeria \\ *Corresponding Author Email: jakpojaro@yahoo.com; Tel: 08138803299
}

\begin{abstract}
Energy is one of the most important factors for accelerating economic development. Due to rapid industrialization and urbanization in Nigeria over the few decades, there is a huge pressure and ever increasing demand of Electrical energy, which has resulted in a concentrated need for finding some alternative sources of energy. Biomass power which is electricity produced from biomass fuel is a renewable energy source steadily gaining importance and leading the way for economic development. Biogas is obtained from biomass waste fermentation process. The paper reviews the potentials of biogas for power generation. A small-scale biogas generation system was designed and implemented. We successfully modified the internal combustion engine, which works smoothly without any sign of audible knocking during the entire experimentation. Comparatively, results show that $1.8 \mathrm{~kg}$ of biogas runs for 127 minutes with a load capacity of 1400 watts while 1 liter of fuel runs on the power generating system with a load input of 1400 watt. 1 liter of fuel operated on the power generating system for a period of 42 minutes after which the system shutdown due to complete consumption of the available fuel. It was observed that as the load input increased, voltage dropped and current increased. Financially $1.8 \mathrm{~kg}$ of biogas costs far less than 1 liter of fuel. Thus, the application of this technology on a large scale in the power sector has significant potentials of increasing the installed electricity capacity being generated in Nigeria. Synergistically, it can help in waste management as well as providing a long-term sustainable approach to energy self-sufficiency and economic development in Nigeria.
\end{abstract}

DOI: https://dx.doi.org/10.4314/jasem.v23i7.17

Copyright: Copyright (C) 2019 Akpojaro et al. This is an open access article distributed under the Creative Commons Attribution License (CCL), which permits unrestricted use, distribution, and reproduction in any medium, provided the original work is properly cited.

Dates: Received: 29 May 2019; Revised: 22 June 2019; Accepted 11 July 2019

Keywords: Energy, Biomass, Biogas production, Biogas purification, Electricity generation.

Energy is one of the most important factors responsible for global development. Its importance cannot be over emphasized. Its use ranges from domestic purposes, industrial and transport purposes. It is also important because it is the cornerstone of economic and social development (Ogundipe et al., 2016). In Nigeria, lack of access to wide range of modern energy services has remained a major barrier to improving key indicators of human development (Greenstone, 2014). This has resulted in less potential energy to harness and drive the economic growth of the country, In aaddition, electricity which is the foundation of modern economies is non-available and if available is of poor quality or better still unreliable as less than 4,000 MW of the 7,876 MW installed electricity capacity is been generated (Sambo, et al., 2010). The non-availability of electricity supply or poor quality and unreliable nature of electricity supply in Nigeria has resulted in the increasing use of stand-by generators of various shapes and sizes (Nkalo and Agwu, 2019). These generators depend entirely on petroleum products such as fuel, diesel, etc. and their combustion bye-products are major contributors to environmental degradation, climate change and global warming (Modi et al.,
2017). Awareness of the limitations of the convectional fuel has enhanced the growing interest in the search for alternate cleaner and sustainable source of energy

Biogas which has a relatively significant comparative advantage due to the country huge biomass potential, which is estimated to be about $8 \times 10^{2}$ MJ offers a promising sustainable solution (Ogwo et al., 2012). However, the wastes are usually dumped indiscriminately in landfills and unauthorized areas contributing further to environmental degradation and global warming. In order to reduce the current over dependence on fossil fuel, enhance energy availability and safeguard the natural eco-system in the face of Nigeria huge biomass potential, biogas technology represents a viable alternative due to its simple technology and rural adaptability (Oyedepo, 2012). Biogas is a fuel gas consisting of a mixture of methane $\left(\mathrm{CH}_{4}\right)$, carbon dioxide $\left(\mathrm{CO}_{2}\right)$ and traces of other gases, produced through microbial processes under anaerobic condition from bio-degradable materials (Divyang and Hemant, 2015). It is a renewable high quality fuel that burns without leaving soot or particulate matter (Khan

*Corresponding Author Email: jakpojaro@yahoo.com; Tel: 08138803299 
et al., 2017). Although biogas technology is yet to be adequately exploited in Nigeria and other Africa countries, the technology is a common place in countries like India, China, Pakistan, U.S.A and most European nations (Gebresemati et al., 2017).

\section{MATERIALS AND METHODS}

This section presents an overview of the system design. One important step taken was to break down the design into core functional blocks in order to simplify the design and construction process. Based on established specifications, a block diagram of the biogas power generation system is presented in Figure 1.

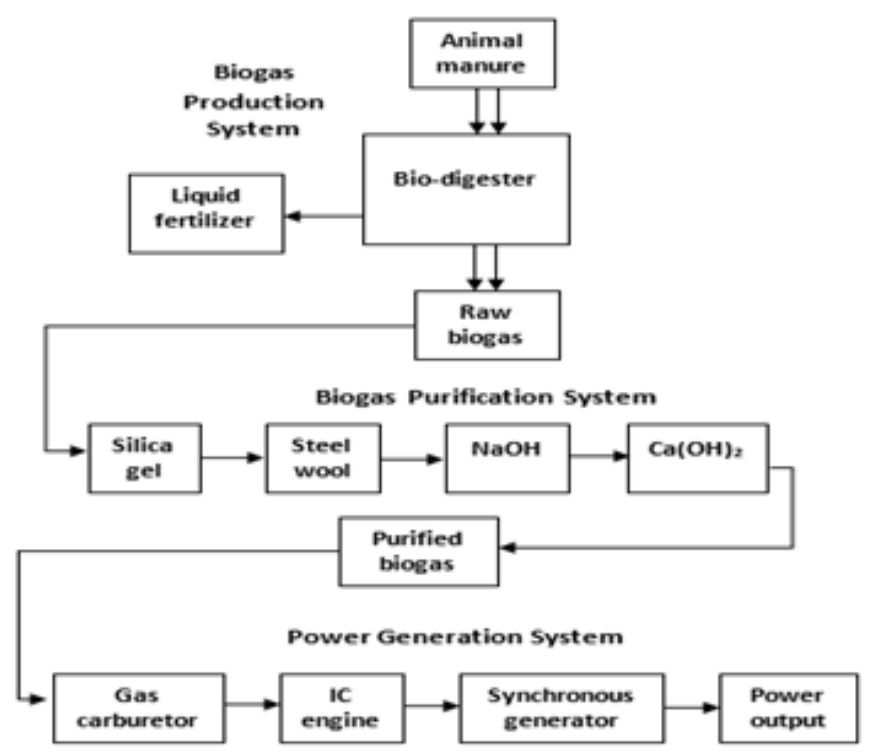

Fig 1: Block diagram of biogas power generation system

Bio-digester Design: As shown in Figure 2, the biodigester vessel was made from a 120 liters plastic drum of diameter $505 \mathrm{~mm}$ and $970 \mathrm{~mm}$ of height. The lid of the vessel was drilled in two places with a hot soldering iron, one at the right side for a $12.7 \mathrm{~mm}$ PVC pipe biogas outlet ducts and the other at the left side for a gas pressure gauge. On the sides of the digester vessel, the substrate inlet duct was created using a $50.8 \mathrm{~mm}$ PVC pipe and ball valve while the slurry outlet ducts were created using a $38.1 \mathrm{~mm}$ PVC pipe and ball valve. All perforations were properly sealed with rubber tubes and adhesives to make the whole bio-digester system airtight.

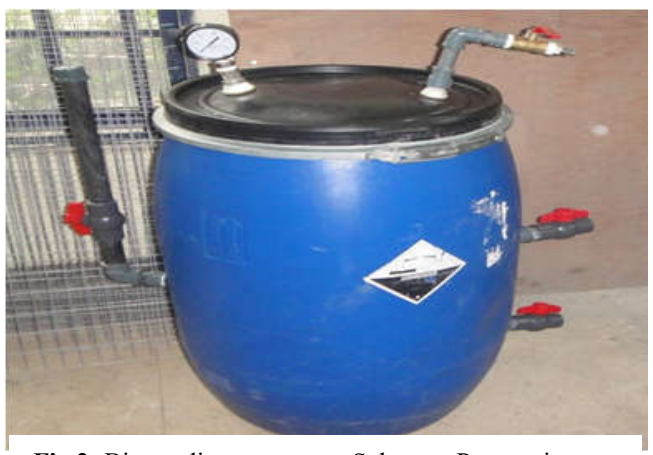

Fig 2: Biogas digester reactor Substrate Preparation: 
The choice of feedstock for this study was cow dung. The choice is due to the abundance of cattle in Nigeria and its numerous advantages (Igiogbe et al., 2015; Abdullahi et al., 2015). The cow dung used for the study was obtained from Gariki Abattoir located at Effurun, Delta State, Nigeria. The fresh cow dung was obtained from animal holding pen unit. The amount of cow dung procured for this study was $40 \mathrm{~kg}$ and it was prepared as followed: the cow dung collected was mixed with water in the ratio $1: 1$ (40kg of cow dung was mixed with 40 liters of water in order to achieve a good slurry and maintain the working volume of the bio-digester at 80 liters).

Experimental Detail: Cow dung and water mixing ratio was $1: 1$ as specified above were fed into the digester and homogenized using a stirrer. The inlet of the digester was covered tightly and padded with rubber seal to ensure that the anaerobic condition was maintained. One end of a rubber hose was connected to the digester gas outlet located at the top of the digester and the other end to a rubber container, which served as the biogas storage facility. The experiment was carried out for 30 days under room temperature.

Biogas Purification System: The utilization of biogas as an efficient energy source depends strongly on its methane concentration (Yentekakis and Goula, 2017; Müller et al., 2017). Therefore, biogas purification was done to remove impurities such as carbon dioxide $\left(\mathrm{CO}_{2}\right)$, hydrogen sulphide $\left(\mathrm{H}_{2} \mathrm{~S}\right)$ and water vapour so as to increase the concentration of methane in the biogas to have fuel of higher calorific value and more energy per unit volume of compressed biogas (Müller et al., 2017). Figure 3 shows the experimental setup for chemical scrubbing of biogas.

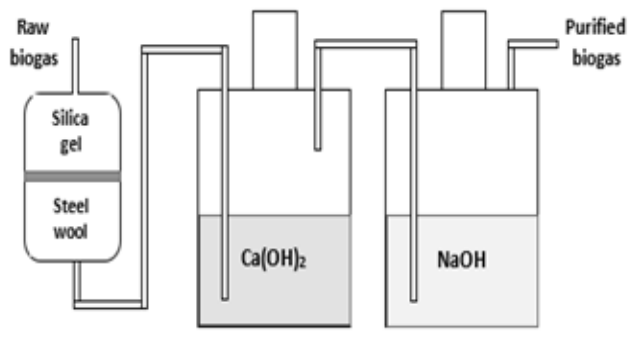

Fig 3: Experimental setup of chemical scrubbing of biogas

As in Figure 3, raw biogas enters from the top of the first chamber containing silica gel and steel wool or iron feelings (chips available from lathe operations) and is passed out from the bottom, removing water vapour and hydrogen sulphide $\left(\mathrm{H}_{2} \mathrm{~S}\right)$. In the second chamber, calcium hydroxide $\left(\mathrm{Ca}(\mathrm{OH})_{2}\right)$ with water was prepared to a concentration of $40 \%$ due to the exothermic reaction and very high amount of heat produced. The gas is passed from top of the chamber containing solution $\mathrm{Ca}(\mathrm{OH})_{2}$ and allowed to bubble in the solution thereby removing some carbon-dioxide $\left(\mathrm{CO}_{2}\right)$. In the third chamber, sodium hydroxide $(\mathrm{NaOH})$ with water was prepared to a concentration of $40 \%$. The gas is passed from top of the chamber containing solution $\mathrm{NaOH}$ and allowed to bubble in the solution thereby removing certain amount of $\mathrm{H}_{2} \mathrm{~S}$ and $\mathrm{CO}_{2}$.

Power Generation System: The power generation system is made up of combination of an internal combustion engine (ICN) (spark ignition engine) and a synchronous generator. To generate electrical power output, a low pressure gas carburetor was incorporated into the ICN to enable the combustion of biogas in the combustion chamber to trigger the engine to produce a torque to rotate the synchronous generator. Modification of Spark Ignition Engine: ignition Modification of the spark engine for biogas utilization does not require an extensive modification or configuration like compression ignition modification. The modification process is simple as spark ignition engines are originally designed to operate on an air/ fuel mixture with spark ignition. Basically, the modification process involves the addition of methane (biogas) - air mixer to the engine (Octaviani and Semin, 2018; Semin, 2015;). For this study, a low pressure gas carburetor was used to convert the IC engine to run on biogas. The engine control was performed by the variation of the mixture supply. The reason for the use of the low pressure gas carburetor in this design was to ensure safety due to its functionality and interface the biogas generation and purification system. The internal combustion engine used for this design is GX160, which has the following specifications as in Table 1.

Table 1: The specifications of the internal combustion engine of GX160

\begin{tabular}{ll}
\hline Material & Specification \\
\hline Engine type & 4-stroke \\
Compression Ratio & $9.0: 1$ \\
Bore x stroke & 68 X 45 mm \\
Starting system & Recoil starter \\
Displacement & $163 \mathrm{~cm}^{3}$ \\
Governor system & Centrifugal Mechanical \\
Net torque & 7.6 lb-ft (10.3Nm) \\
Net power output & $5.5 \mathrm{HP} \mathrm{@} \mathrm{3000-3600} \mathrm{rpm}$ \\
PTO Shaft Rotation & Counterclockwise \\
Dimensions: & Length: 312mm \\
& Width: $362 \mathrm{~mm}$ \\
& Height: $346 \mathrm{~mm}$ \\
\hline
\end{tabular}


Synchronous Generator Parameters: The synchronous generator unit is shown in Figure 4. It is made up of a salient pole rotor, a stator and armature. The electrical parameters of the synchronous generator used in this design are specified in Table 2.

\begin{tabular}{ll}
\multicolumn{1}{c}{ Table 2: Electrical parameters of the synchronous generator } \\
\hline Material & Parameter specification \\
\hline Phase & Single phase \\
Number of pole & 2 poles \\
Number of slots & 26 slots; 20 slots for field windings \\
& and 6 slots for excitation windings \\
Voltage & $220 \mathrm{~V}$ \\
Frequency & $50 \mathrm{~Hz}$ \\
Speed of rotor in & $3000 \mathrm{rpm}$ \\
r.p.m. & \\
Number of turns: & Field windings: 24 turns double \\
& layer winding \\
& Excitation windings: 80 turns / \\
Coil gauge: & single layer winding \\
& Field windings: $21 / 22 \mathrm{SWG}$ \\
Winding factor & Excitation windings: $24 / 25 \mathrm{SWG}$ \\
Rotor windings & 1 \\
Stator frame diameter & $0.5 \mathrm{~kg}$ of $24 / 25 \mathrm{SWG}$ \\
Stator frame length & $385.5 \mathrm{~mm}$ \\
Power & $302.8 \mathrm{~mm}$ \\
Power factor & $2500 \mathrm{~W} / 2.5 \mathrm{KVA}$ \\
Torque & 1 \\
\hline
\end{tabular}

Implementation: The implementation process took place in stages so as to simplify the entire process. The system was constructed in modules as designed and later put together on completion to simplify construction, testing and maintenance. Figure 5 shows the biogas production and purification system. The biogas production system consists of biogas digester constructed using the fabrication process stated in the design analysis.

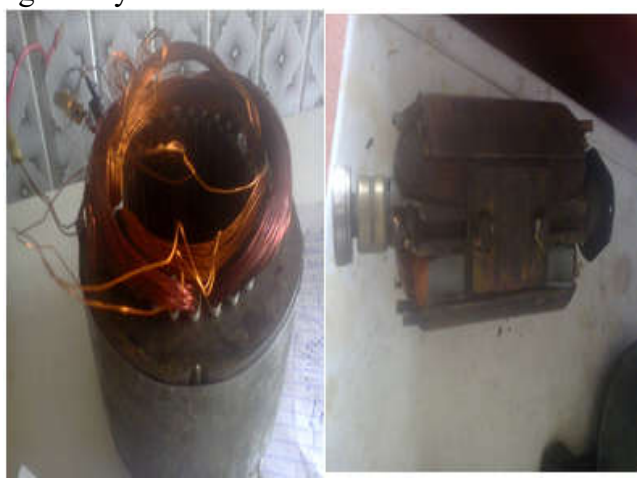

Fig 4: Synchronous generator.

The purification system was constructed using a $76.2 \mathrm{~mm}$ pipe with both ends covered to store silica gel and steel wool and two plastic bottles (used for storing reverse osmosis processed potable drinking water) with necessary pipe fittings were used to construct the storage for $\mathrm{NaOH}$ and $\mathrm{Ca}(\mathrm{OH})_{2}$ to facilitate the chemical scrubbing of raw biogas. The biogas production and purification system was interfaced using rubber hose to pass the produced biogas from one stage to another. The purified biogas was stored in a tyre tube and a carriage was fabricated using a $2 \mathrm{~mm}$ and $1 \mathrm{~mm}$ angle bar to make the system mobile.

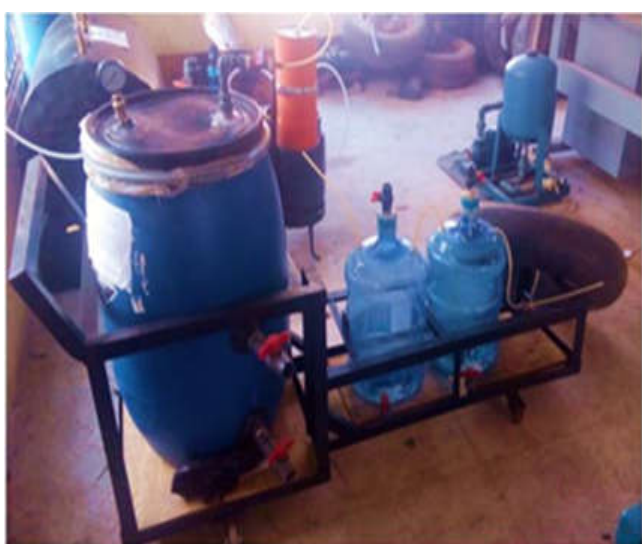

Fig 5: Biogas production and purification system

Figure 6 shows the power generation system, which consists of an internal combustion engine, a low pressure gas carburetor and a synchronous generator. The system uses the GX160 internal combustion engine. It was modified by reconfiguring the carburetor using a low pressure gas carburetor. The synchronous generator was directly coupled to the internal combustion engine. Sockets, lamp holders and switches where wired on a wooden board to get the power output from the synchronous generator. A frame was fabricated using $1.5 \mathrm{~mm}$ angle bar to sit the internal combustion engine and the synchronous generator. Dampers were used to reduce the vibration produced by the engine. Figure 7 shows the biogas production, purification and power generation system.

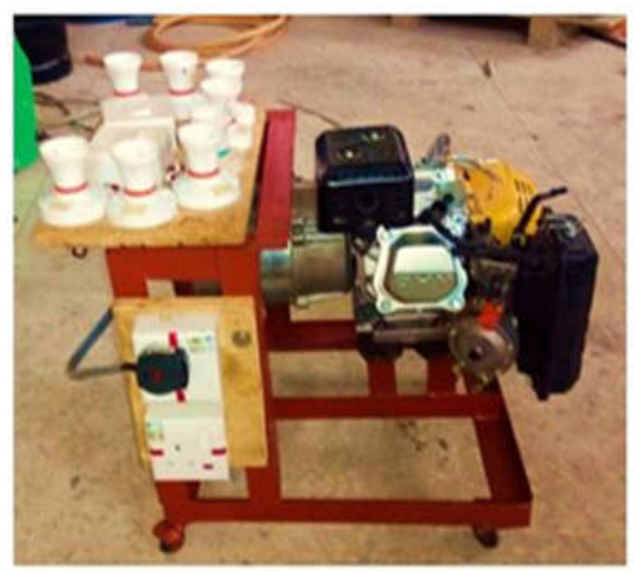

Fig 6: Power generation system. 


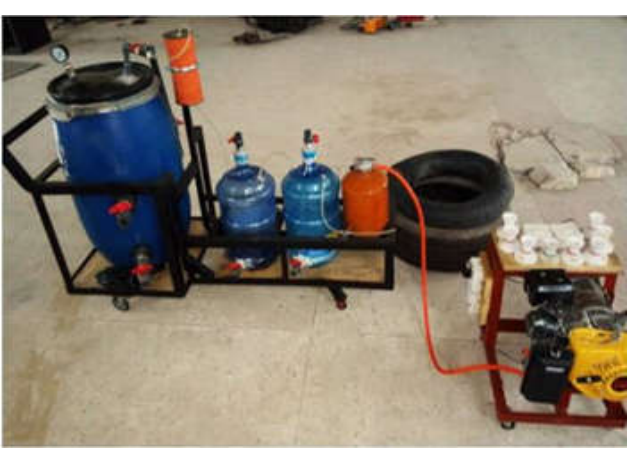

Fig 7: Biogas production, purification and power generation system

The problems encountered in the implementation is as follows: i) Due to the material selection for the fabrication of the bio-digester and purification system, there were gas leakage as a result of built up pressure within the system thereby causing expansion on the material. Thus, this reduced the gas production efficiency of the system. ii) Using biogas to power a conventional gasoline generator converted to function on gas using a low pressure gas carburetor proved a bit difficult as there was a need to always regulate the biogas input pressure when interfaced with the gas carburetor to power on the generator.

\section{RESULTS AND DISCUSSION}

Data obtained from this study revealed that biogas production was actually slow at the start and end of production. This result was due to the slow activity level of the methanogenic bacteria, as gas production rate is directly equal to the specific growth of methanogenic bacteria. For this work, $40 \mathrm{~kg}$ of cow dung was used. From the biogas production and purification system $1.565 \mathrm{~m}^{3}$ of purified biogas was generated after a retention period of 30 days which was compressed into a $3 \mathrm{~kg}$ gas cylinder using a refrigerator compressor given a mass of $1.8 \mathrm{~kg}$ and a total mass of $4.8 \mathrm{~kg}$. The produced biogas was used to run the power generating system.

Flammability Test: The test was carried out using a $6.35 \mathrm{~mm}$ hose. One end of the hose was connected to the bio-digester gas outlet duct and the other connected to a burner. The gas outlet valve was opened and the burner was ignited using a fire starter (lighter) to test for the presence of methane in the biogas produced. From the test, it was observed that the biogas burnt producing a pale blue flame as shown in Figure 8. This result corroborates Joshi, et al., (2017).

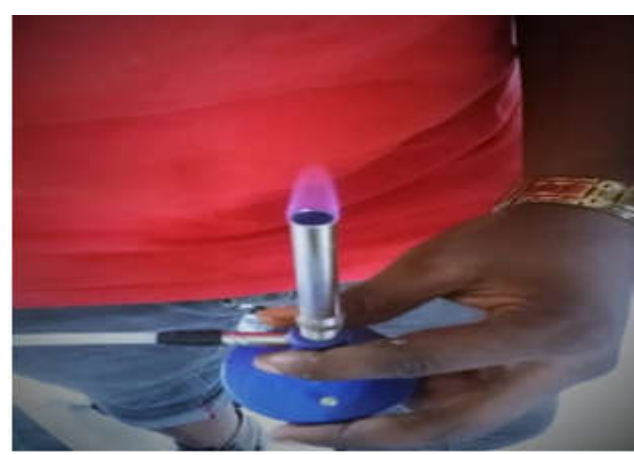

Fig 8: Flammability Test

Electricity Production from Biogas: From the biogas production and purification system, $1.565 \mathrm{~m}^{3}$ of purified biogas was generated. To determine the electricity production rate of the biogas generated, the volume of biogas was converted into mega joules after which it was converted from mega joules to kilowatthour and multiplied by its percentage useful energy (Semin et al., 2016; Joshi et al., (2017).

Biogas production rate $=1.565 \mathrm{~m}^{3}$

Converting the volume of biogas produced to mega joules

$$
1 \mathrm{~m}^{3} \text { of biogas }=19 \text { mega joules }
$$

$1.565 \mathrm{~m}^{3}$ of biogas $=1.565 \mathrm{~m}^{3} \times 19$ mega joules

$$
=29.7 \text { mega joules }
$$

Converting to kilowatt-hour $=29.7$ mega joules $/ 3.6=$ $8.26 \mathrm{kWh}$.

When biogas was converted into electrical energy, $65 \%$ of the energy lost as heat and other mechanical losses as utilized by the electricity generator (Niemczewska, 2012). Therefore, the electrical energy used for the generation of electricity becomes $35 \%$ of the kilowatt-hour.

$35 \%$ of $8.26 \mathrm{kWh}=0.35 \times 8.26 \mathrm{kWh}=2.88 \mathrm{kWh}$ From the above result, $2.88 \mathrm{kwh}$ is the electricity generated using $1.565 \mathrm{~m}^{3}$ of biogas.

Comparative Analysis of Biogas and Petrol Consumption with Load: Comparative analysis of biogas and petrol consumption with load was carried out with respect to the quantity and load input on the power generation system. For biogas consumption analysis, the consumption rate was observed with respect to time. The biogas was scaled before and after it was run on the power generating system with a load input of 1400 watt. Biogas was run on the power generating system for a period of 60 minutes after which it was scaled. It was observed that $0.85 \mathrm{~kg}$ of 
biogas was consumed. Therefore, $1 \mathrm{~kg}$ of biogas will run for:

$$
\begin{aligned}
& \text { If } 0.85 \mathrm{~kg} \text { run for } 60 \text { minutes, } 1 \mathrm{~kg} \text { will run for } \mathrm{x} \\
& 0.85 \mathrm{~kg}=60 \text { minutes } \\
& 1 \mathrm{~kg}=\mathrm{X} \text { minutes } \\
& \mathrm{X} \text { minutes }=60 \text { minutes } / 0.85=71 \text { minutes }
\end{aligned}
$$

From the above result, $1 \mathrm{~kg}$ of biogas will run for 71 minutes with a load capacity of 1400 watts.

For the total biogas production of $1.8 \mathrm{~kg}, 1.8 \mathrm{~kg}$ will run for:

$$
\begin{aligned}
& \text { If } 0.85 \mathrm{~kg} \text { run for } 60 \text { minutes, } 1.8 \mathrm{~kg} \text { will run for } \mathrm{x} \\
& \text { minutes } \\
& 0.85 \mathrm{~kg}=60 \text { minutes } \\
& 1.8 \mathrm{~kg}=\mathrm{X} \text { minutes } \\
& \mathrm{X} \text { minutes }=60 \text { minutes } \times 1.8 / 0.85=127 \text { minutes }
\end{aligned}
$$

From the above result, $1.8 \mathrm{~kg}$ of biogas will run for 127 minutes with a load capacity of 1400 watts.

For petrol consumption analysis, 1 liter of petrol was run on the power generating system with a load input of 1400 watt. 1 liter of petrol operated on the power generating system for a period of 42 minutes after which the system shutdown due to complete consumption of the available petrol (next work would consider other factors that might affect how long the generator set lasts, e.g., age of the engine, etc.). Therefore 1 liter of petrol will run for 42 minutes with a load capacity of 1400 watts. From the consumption analysis of biogas and petrol, biogas obtained the longer lasting time with respect to the same load input and burnt cleaner releasing even lesser heat than petrol (Amakom, 2015).

Electricity Voltage Output and Load Bearing Characteristics: From the performance evaluation of the power generation system, the modified internal combustion engine worked smoothly without any sign of audible knocking during the entire load range. The observed favorable characteristic was the confirmation of a successful modification process and anti-knocking properties of biogas. At variable range of electrical loading, there was a change in modified internal combustion engine characteristics as a function of added load. The modified engine at load condition of $100 \mathrm{~W}$ to $1400 \mathrm{~W}$ operated smoothly with synchronous generator given a voltage output of $220 \mathrm{~V}$ to $199 \mathrm{~V}$ due to load increase comparable to the modified engine run on petrol at equal load level.

Table 3: Current output/Load bearing capacity assessment.

\begin{tabular}{lll}
\hline \multicolumn{3}{c}{ Current Reading } \\
\hline Load (Watts) & Biogas (A) & Petrol (A) \\
\hline 100 & 0.48 & 0.5 \\
\hline
\end{tabular}

\begin{tabular}{lll}
\hline \multicolumn{3}{c}{ Current Reading } \\
\hline Load (Watts) & Biogas $(\boldsymbol{A})$ & Petrol $(\boldsymbol{A})$ \\
\hline 200 & 0.87 & 0.92 \\
300 & 1.36 & 1.43 \\
400 & 1.82 & 1.82 \\
500 & 2.31 & 2.34 \\
600 & 2.72 & 2.75 \\
700 & 3.19 & 3.23 \\
800 & 3.54 & 3.77 \\
900 & 4.00 & 4.25 \\
1000 & 4.56 & 4.64 \\
1100 & 5.00 & 5.10 \\
1200 & 5.34 & 5.47 \\
1300 & 5.78 & 5.89 \\
1400 & 6.17 & 6.34 \\
\hline
\end{tabular}

Table 4: Voltage output/Load bearing capacity assessment

\begin{tabular}{lll}
\hline \multicolumn{3}{c}{ Voltage Reading } \\
\hline Load (Watts) & Biogas (V) & Petrd (V) \\
100 & 220 & 223.2 \\
200 & 219 & 222.2 \\
300 & 218 & 221.5 \\
400 & 217 & 220.4 \\
500 & 216 & 219.9 \\
600 & 215 & 218.5 \\
700 & 213 & 216.9 \\
800 & 210 & 215.1 \\
900 & 208 & 214.1 \\
1000 & 206 & 212.2 \\
1100 & 203 & 211.2 \\
1200 & 202 & 210.2 \\
1300 & 200 & 208.2 \\
1400 & 199 & 206.5 \\
\hline
\end{tabular}

The optimal performance of the engine at $100 \mathrm{~W}$ to $1400 \mathrm{~W}$ was partly due to the scrubbing efficiency of the scrubbing chamber which considerably reduced the carbon dioxide content of the raw biogas and improved the biogas thermal efficiency. A comparative analysis was made on the modified internal combustion engine running on biogas and petrol. Voltage and current readings were taking from the synchronous generator using a multimeter at different load input ranging from $100 \mathrm{~W}$ to $1400 \mathrm{~W}$. It was observed that as the load input increased, voltage dropped and current increased as shown in Table 3 and Table 4 (test of statistical significance would be presented in another work). These results corroborate Joshi et al., (2017).

Conclusion: The paper reviews the potentials of biogas for power generation. A small-scale biogas generation system was designed and implemented. We successfully modified the internal combustion engine, which works smoothly without any sign of audible knocking during the entire experimentation. Comparatively, our result shows that $1.8 \mathrm{~kg}$ of biogas runs for 127 minutes with a load capacity of 1400 Watts while 1 liter of fuel runs on the power generating system with a load input of 1400 Watts. 1 liter of fuel operated on the power generating system for a period 
of 42 minutes after which the system shutdown due to complete consumption of the available fuel. However, apart from the fact that $1.8 \mathrm{~kg}$ of biogas costs far less than 1 liter of fuel, synergistically, application of this technology can help in waste management as well as providing a long-term sustainable approach to energy self-sufficiency and economic development in Nigeria.

\section{REFERENCES}

Abdullahi, US; Daneyel, HN; Aliyara, YH. (2015). Grazing Reserves and Pastoralism in Nigeria: A Review. Vom J. Vet. Sci.10: 137 - 142.

Amakom, CN. (2015). Comparative Analysis on the Biogas Yield for Chicken Droppings and Cow Dung. 5th Annual \& International Conference on Renewable Energy for Sustainable Environment, 18th-21st June 2015, At Gregory University, Uturu, Abia State, Nigeria, Volume: 5

Divyang, S.; Hemant, N. (2015). Low Cost Biogas Purification System for Application of Bio CNG as Fuel for Automobile Engines. Inter. J. Innov. Sci. Engineer. Technol. 2(6): 310-311.

Gebresemati, M.; Das, G.; JuPark, B.; Hee-Yoon, H. (2017). Electricity production from macroalgae by a microbial fuel cell using nickel nanoparticles as cathode catalysts. Inter. J. Hydrogen Energy, 42(50): 29874-29880.

Greenstone, M. (2014). Evidence Paper: Energy, Growth and Development. International Growth Centre (IGC), pp 2.42.

Igiogbe, I; Fasipe, I; Chukwudi, E. (2015). Impact of Livestock Grazing on Abundance and Community Structure of Macro-invertebrate Fauna of Ovia River, Edo State, Nigeria. J. Appl. Sci. Environ. Manage. 19 (4): 779 - 784.

Joshi, A.; Jose, J.; Bansiwal, N.; Soni, N. (2017). Study on Electricity Generation through biogas on small scale. Inter. J. Innov. Res. Sci. Engineer. Technol. 6 (4): 6662-6669

Khan, IU; Othman, MHD; Hashim, H; Matsuura, T; Ismailb, AF; Rezaei-DashtArzhandib, MI; Azeleeb, W.(2017). Biogas as a Renewable Energy Fuel - A Review of Biogas Upgrading, Utilization and Storage. Energy Conversion and Management, 150: 277 - 294.

Modi, A.; Singh, S.; Verma, N. (2017). Improved performance of a single chamber microbial fuel cell using nitrogen-doped polymer-metal-carbon nanocomposite-based air-cathode. Inter. $J$. Hydrogen Energy. 42(5): 3271-3280.

Müller, FPC; Maack, GC; Buescher, W. (2017). Effects of Biogas Substrate Recirculation on Methane Yield and Efficiency of a LiquidManure-Based Biogas Plant. Energies, 10, 325;

Niemczewska, J. (2012). Characteristics of Utilization of Biogas Technology. NAFTA-GAZ, ROK LXVIII, pp. 293 - 297.

Nkalo, UK; Agwu, EO. (2019). Impact of Electricity Supply on Economic Growth: A Nigerian Case Study. J. Elec. Elect. Engineer. 14(1): 28 - 34.

Octaviani, NS; Semin. (2018). Technical Overview of Biogas Utilization as Fuel of Boat Engine. Inter. J. Mar. Engineer. Inno. Res. 2(2): 171-175.

Ogundipe, AA; Akinyemi, O.; Ogundipe, OM. (2016). International Journal of Energy Economics and Policy. Inter. J Energy Eco.Policy, 6(1): 134 -143.

Ogwo1, JN.; Dike, OC.; Mathew, SO.; Akabuogu, EU. (2012) Overview of Biomass Energy Production in Nigeria: Implications and Challenges. Asian J. Nat. Appl. Sci. 1(4): 46 - 51.

Oyedepo, SO. (2012): Renewable and Sustainable Energy Reviews. Renewable and Sustainable Energy Reviews, 16: 2583-2598.

Sambo, AS.; Garba, B.; Zarma, IH.; Gaji, M. M. (2010). Electricity Generation and the Present Challenges in the Nigerian Power Sector. Energy commission of Nigeria, Energy Resources Review, 10: 1-17.

Semin (2015). Analysis of Biogas as an Alternative Fuel for Electric Generator Engine in Bawean Island - Indonesia, Inter. J. Appl. Engineer. Res. 10(15): 35313-35317.

Semin, Octaviani, NS; Gusti, AP; Zaman, MB (2016). Power Performance Characteristics Investigation of Gas Engine using New Injector. Inter. J. Appl. Engineer. Res. 11(11): 7462-7466.

Yentekakis, IY; Goula, G. (2017). Biogas Management: Advanced Utilization for Production of Renewable Energy and Addedvalue Chemicals. Frontiers Environ. Sci. 6(7): 118. 